BEHAVIOUR

\title{
Sexual risk behaviour among Surinamese and Antillean migrants travelling to their countries of origin
}

\author{
M A Kramer, A van den Hoek, R A Coutinho, M Prins
}

Sex Transm Infect 2005;81:508-510. doi: 10.1136/sti.2004.014282

\begin{abstract}
Objectives: To examine travel related sexual risk behaviour among migrants living in Amsterdam.

Methods: People originating from Surinam $(n=798)$ and the Netherlands Antilles $(n=227)$ were recruited in order to study the heterosexual spread of HIV within ethnic groups. Log binomial regression was used to study determinants for homeland travel over the past 5 years; logistic regression was used to study determinants of unprotected sex on these visits.

Results: Of the migrants, $38 \%$ of men and $42 \%$ of women visited their homeland. Visits were most likely among men who had lived $\geqslant 7$ years in the Netherlands, were employed, had a high educational level and were/had been married. For women, visiting was associated with older age and living in the Netherlands for $\geqslant 8$ years. Of migrants visiting their homeland, $47 \%$ of men and $11 \%$ of women acquired a local sexual partner. For male travellers, Surinamese origin (adjusted OR 10.66; 95\% Cl 1.72 to 104.48) and a history of $\geqslant 1$ sexually transmitted infection (STI) (adjusted OR 12.51 ; $95 \% \mathrm{Cl} 3.75$ to 46.95 ) were associated with having unprotected sex with local partners. For women, having $>1$ partner in the past 5 years (OR 13.57; $95 \% \mathrm{Cl} 2.57$ to 250.28) was associated with unprotected sex with local partners.

Conclusion: Migrants are at substantial risk for HIV and STls while visiting their homeland. It is important to reach migrants, who are likely to engage in unprotected sex during visits, for pretravel health education. Additional research on risk behaviour in the homeland and the Netherlands is needed to identify migrants with high risk behaviour.
\end{abstract}

I the Netherlands, the proportion of heterosexual people among the HIV infected population is rising. A substantial proportion of these individuals have a non-Dutch background, with $21 \%$ being originally from Surinam, the Netherlands Antilles, and Aruba. ${ }^{1}$ A previous study among Surinamese, Antillean, and sub-Saharan migrants living in the Netherlands reported high rate of partner change, concurrent partnerships, and history of sexually transmitted infections (STI). ${ }^{2}$ In a study among sub-Saharan Africans living in London, $40 \%$ of the men and $20 \%$ of the women had acquired a new sexual partner while travelling abroad. ${ }^{3}$ Unprotected sex in the homeland could be an important risk factor for HIV infection, because the estimated prevalence rates for Surinam, the Antilles, and Aruba are 90, 50, and 21 HIV cases per 100000 population, respectively, versus 10 cases per 100000 population in the Netherlands. ${ }^{145}$ Moreover, molecular epidemiological research suggests an increased risk for importing HIV infection. Half of the HIV positive people originating from Surinam and the Antilles are believed to have been infected during a homeland visit. ${ }^{6}$
Since more insight into sexual risk behaviour on homeland visits is needed to develop prevention measures, we studied the characteristics of Surinamese and Antillean men and women who visit their homeland and the determinants of having unprotected sex during those visits.

\section{METHODS}

\section{Study population}

In a study in the south eastern area of Amsterdam 1660 people originating from Surinam, the Antilles, and subSaharan Africa were recruited from May 1997 to July 1998 in market places, shopping areas, community houses, and churches. ${ }^{2}$ Inclusion criteria for the present study were age between 15 years and 55 years and self identification as Surinamese or Antillean $(n=1025)$. After oral informed consent, saliva was taken and tested for antibodies against HIV. Interviews took place using a structured questionnaire concerning demographics, mobility, and sexual behaviour. Participants were asked about the number of homeland visits in the past 5 years, the local sexual contacts during those visits, and condom use with those contacts.

The study was approved by an ethics committee.

\section{Definition of variables and statistical analyses}

In this study we determined variables associated with (1) visiting the homeland and (2) having unprotected sex on visits. Unprotected sex in the homeland was defined as: a lack of consistent condom use (that is, not always) when having sex with local partner(s) during visits in the past 5 years.

When the prevalence of an outcome is high, odds ratios can be misleading if interpreted as relative risks. ${ }^{7}$ Because the prevalence of homeland visits was high in this study, prevalence rate ratios instead of odds ratios were used to describe the association between such travel and its determinants. The analyses were done with GENMOD procedure, using a generalised linear model for binomial outcomes with a logarithmic link function. Logistic regression was used to study determinants of unprotected sex on homeland visits. Variables with a $\mathrm{p}<0.10$ in univariate analysis were entered into the multivariate model.

\section{RESULTS}

\section{General characteristics}

The total study population consisted of 494 men and 531 women. The majority of men (79\%) and women (77\%) were Surinamese (table 1). The median age of men was 28 years and their median length of stay in the Netherlands was 10 years (interquartile range (IQR) 19-37 years). For women, the median age was 31 years (IQR 3-21 years), and their median length of stay was 11 years (IQR 5-22 years). Compared with Surinamese, both Antillean men and women

Abbreviations: IQR, interquartile range; PRR, prevalence rate ratio; STI, sexually transmitted infections 


\begin{tabular}{|c|c|c|c|c|}
\hline & \multicolumn{2}{|l|}{ Men } & \multicolumn{2}{|l|}{ Women } \\
\hline & \multirow{2}{*}{$\begin{array}{l}\text { Surinamese, } \\
n(\%) \\
(n=390)\end{array}$} & \multirow{2}{*}{$\begin{array}{l}\text { Antillean, } \\
\mathrm{n}(\%) \\
(\mathrm{n}=104)\end{array}$} & \multirow{2}{*}{$\begin{array}{l}\text { Surinamese, } \\
n(\%) \\
(n=408)\end{array}$} & \multirow{2}{*}{$\begin{array}{l}\text { Antillean, } \\
n(\%) \\
(n=123)\end{array}$} \\
\hline & & & & \\
\hline \multicolumn{5}{|l|}{ Age (years) } \\
\hline Median (IQR)* & $27(20-37)$ & $29(19-37)$ & $31(22-39)$ & $32(24-39)$ \\
\hline \multicolumn{5}{|l|}{ Length of stay (years) } \\
\hline Median (IQR) $)^{*}$ & $11(5-21)$ & $8(3-11)$ & $14(5-22)$ & $9(5-15)$ \\
\hline \multicolumn{5}{|l|}{ Employment status } \\
\hline Employed & $153(39)$ & $22(21)$ & $162(40)$ & $40(33)$ \\
\hline Unemployed & $119(31)$ & $51(49)$ & $63(15)$ & $26(21)$ \\
\hline At school & 111 (29) & $31(30)$ & $101(25)$ & $18(15)$ \\
\hline At home & $4(1)$ & - & $82(20)$ & $39(32)$ \\
\hline \multicolumn{5}{|l|}{ Education level } \\
\hline Low & $206(53)$ & $81(78)$ & $219(54)$ & $79(64)$ \\
\hline Middle & $144(37)$ & $16(15)$ & $142(35)$ & $33(27)$ \\
\hline High & $40(10)$ & $7(7)$ & $47(12)$ & 11 (9) \\
\hline \multicolumn{5}{|l|}{ Living together with } \\
\hline Nobody & $110(28)$ & $40(39)$ & $35(9)$ & $14(11)$ \\
\hline Partner and/or child & $103(26)$ & $19(18)$ & $253(62)$ & 79 (64) \\
\hline Family & $167(43)$ & $39(38)$ & $117(29)$ & $28(23)$ \\
\hline \multicolumn{5}{|l|}{ Marital status } \\
\hline Single & $318(82)$ & $83(80)$ & $277(68)$ & $91(74)$ \\
\hline Married & $30(8)$ & $6(6)$ & 47 (12) & 17 (14) \\
\hline Divorced/widow & $39(10)$ & $14(14)$ & $84(21)$ & $15(12)$ \\
\hline No health insurance & $35(9)$ & $13(13)$ & $11(3)$ & $2(2)$ \\
\hline Previous HIV test & $72(19)$ & $31(30)$ & $155(38)$ & $58(47)$ \\
\hline Previously diagnosed STI & $145(37)$ & $29(28)$ & $84(21)$ & 17 (14) \\
\hline HIV prevalence & $3(0.8)$ & $3(2.9)$ & $1(0.3)$ & $1(0.8)$ \\
\hline
\end{tabular}

reported more often a previous HIV test and less frequently a diagnosed STI. More than $50 \%$ of the men and women from both countries had a low educational level (that is, lower vocational education), and $82 \%$ of the men and $69 \%$ of the women were single. HIV prevalence was $0.8 \%$ (95\% CI 0.3 to $1.5)$.

\section{Travelling to country of origin}

Over 5 years, $38 \%$ of the 494 men and $42 \%$ of the 531 women visited their homeland. In multivariate analysis, married and divorced men (prevalence rate ratio (PRR) 1.37, 95\% CI 1.07 to 1.57 ) and men living in the Netherlands $\geqslant 7$ years (PRR $1.42 ; 95 \%$ CI 1.12 to 1.65$)$ were more likely to visit their

\begin{tabular}{|c|c|c|c|c|c|c|c|}
\hline & \multirow{2}{*}{$\begin{array}{l}\text { Total } \\
\text { number }\end{array}$} & \multirow{2}{*}{$\begin{array}{l}\text { Prevalence } \\
\text { unprotected } \\
\text { sex (\%) }\end{array}$} & \multicolumn{2}{|c|}{ Univariate } & \multirow[b]{2}{*}{$p$ Value } & \multicolumn{2}{|c|}{ Multivariate } \\
\hline & & & $\mathrm{OR}^{*}$ & $95 \% \mathrm{Cl}^{*}$ & & $\mathrm{OR}^{*}$ & $95 \% \mathrm{Cl}^{*}$ \\
\hline Men & 186 & & & & & & \\
\hline Age per 10 years & & & 1.83 & (1.27 to 2.68$)$ & & 1.33 & (0.75 to 2.34$)$ \\
\hline \multicolumn{8}{|l|}{ Dutch residence } \\
\hline $0-7$ years & 50 & 14 & 1.00 & & & 1.00 & \\
\hline $7-17$ years & 72 & 8 & 0.56 & (0.17 to 1.79$)$ & & 0.59 & (0.15 to 2.26$)$ \\
\hline$>17$ years & 64 & 28 & 2.40 & $(0.95$ to 6.70$)$ & 0.007 & 1.09 & (0.30 to 4.07$)$ \\
\hline \multicolumn{8}{|l|}{ Living together with } \\
\hline Nobody & 59 & 29 & 1.00 & & & 1.00 & \\
\hline Partner/children/family & 125 & 11 & 0.31 & $(0.14$ to 0.69$)$ & 0.003 & 0.41 & $(0.14$ to 1.20$)$ \\
\hline \multicolumn{8}{|l|}{ Ethnic origin } \\
\hline Antillean & 34 & 6 & 1.00 & & & 1.00 & \\
\hline Surinamese & 152 & 19 & 3.77 & $(1.06$ to 24.10$)$ & 0.039 & 10.66 & (1.72 to 104.48$)$ \\
\hline \multicolumn{8}{|l|}{ Lifetime STI } \\
\hline Never & 118 & 7 & 1.00 & & & 1.00 & \\
\hline 1 & 38 & 21 & 3.67 & (1.25 to 10.77$)$ & & 2.32 & (0.69 to 7.79 ) \\
\hline$>1$ & 29 & 52 & 14.73 & (5.46 to 42.94 ) & $<0.001$ & 12.51 & (3.75 to 46.95 ) \\
\hline \multicolumn{8}{|l|}{ Hard drug use ever } \\
\hline No & 162 & 14 & 1.00 & & & 1.00 & \\
\hline Yes & 24 & 33 & 3.02 & (1.12 to 7.73$)$ & 0.030 & 2.07 & (0.54 to 7.85$)$ \\
\hline \multicolumn{8}{|c|}{ Paid sexual contacts since 1980} \\
\hline Yes & 72 & 29 & 1.00 & & & 1.00 & \\
\hline No & 114 & 9 & 0.30 & $(0.14$ to 0.58$)$ & $<0.001$ & 0.58 & $(0.19$ to 1.76$)$ \\
\hline Women & 222 & & & & & & \\
\hline \multicolumn{8}{|c|}{ Number of partners past 5 years } \\
\hline 0-1 & 117 & 1 & 1.00 & & & & \\
\hline$>1$ & 105 & 11 & 13.57 & (2.57 to 250.28 ) & $<0.001$ & & \\
\hline
\end{tabular}


homeland than single men and men living in the Netherlands for $<7$ years. Compared to unemployed men, employed men travelled more frequently (PRR 1.48; 95\% CI 1.14 to 2.05). Homeland visits were more often observed among men with high educational level (that is, higher vocational education/university) compared to those with low educational level (PRR 1.53, 95\% CI 1.16 to 1.62 ).

Women with age $\geqslant 36$ years (PRR $1.48,95 \%$ CI 1.05 to 2.16) were more likely to visit their homeland than women younger than 36 years. Those who were living in the Netherlands for $\geqslant 8$ years (PRR 1.34, 95\% CI 1.06 to 1.71 ) travelled more often than women who were living in the Netherlands for $<8$ years.

\section{Unprotected sex with partner in country of origin}

Of the 186 men who travelled to their homeland, $47 \%$ acquired a local sexual partner, as did $11 \%$ of the 222 women. Unprotected sex with local partners occurred in 31/87 (36\%) of these men and in 12/24 (50\%) of the women.

Having $>1$ partner in the past 5 years was, among female travellers, the only variable significantly (OR: 13.57) associated with unprotected sex with local partners. Other variables did not confound this association. In multivariate analysis, Surinamese men had a 10.7-fold higher odds of having unprotected sex in their homeland than did Antillean men. Men with a history of $\geqslant 1$ STI had a 12.5-fold higher odds of having unprotected sex than men without a history of STI (table 2).

\section{DISCUSSION}

The relation of the Netherlands with former colonies enables mobility of migrants. Of our respondents, $40 \%$ visited their homeland in a 5 year period. In line with our results, a study among sub-Saharan Africans in London has shown that homeland travel is associated with UK residence for more than 10 years, a high education level, and full time employment. $^{3}$

Men were more likely than women to establish new sexual relationships in their homeland. However, among all those with such a relationship, the percentage of unprotected sex was higher for women. Clearly, both men and women are vulnerable to HIV infection and other STIs while travelling.

Research regarding sexual risk behaviour while travelling to the country of origin is limited. ${ }^{3}$

In line with our and the London study, studies among expatriates and holiday makers report percentages of sex with new partners of $5 \%$ and $60 \%{ }^{8-11}$ They also identified a significant association between multiple sexual partners in country of residence and unprotected sex during visits. We also found that ethnicity and a history of $\geqslant 1$ STI were associated with unprotected sex while travelling. This is inconsistent with findings from studies among expatriates and holiday makers. ${ }^{8911}$ Just like expatriates and holiday makers, migrants have a "bridge function" between areas with high and low HIV prevalence. Their sexual risk behaviour in the homeland and in the Netherlands acts as a bridge between two heterosexual populations. ${ }^{8} 9^{11} 12$

Therefore, such behaviour of migrants in both their past and present countries should be studied in more detail. Findings will help to differentiate migrant cultures and to identify travellers at high risk for STIs and HIV infection. Education and effective pretravel counselling on sexual behaviour should target migrant travellers who are likely to engage in sexual risk behaviour.

\section{ACKNOWLEDGEMENTS}

This study was funded by the Dutch Health Research and Development Council (grant no 2829590) and by the AIDSFoundation, the Netherlands (grant no 7015).

The authors would like to thank Mitzi Gras, Jessica Weide, Steve Deul, David Addo, and Mirjam Poley for the realisation of this project; the participants for their willingness to cooperate; Ronald Geskus and Eline Op de Coul for critically reading this manuscript; and Lucy Philips for editing the final manuscript.

\section{CONTRIBUTORS}

MK performed the statistical analysis and prepared this manuscript; AvdH was involved in the design and implementation of the study; MP was the project leader of the present study and was involved in the statistical analysis; RC was the principal investigator of the study; all authors were involved in the preparation of the final manuscript.

\section{Authors' affiliations}

M A Kramer, A van den Hoek, R A Coutinho, Cluster Infectious Diseases, Health Service Amsterdam, Netherlands

R A Coutinho, M Prins, Department of Human Retrovirology, Academic Medical Service Center, University of Amsterdam, Netherlands

There is no conflict of interest.

Correspondence to: M A Kramer, Health Service Amsterdam, Cluster of Infectious Diseases, HIV\&STI Research, Nieuwe Achtergracht 100, PO Box 2200, 1000 CE Amsterdam, Netherlands; mkramer@gggd. amsterdam.nl

Accepted for publication 29 March 2005

\section{REFERENCES}

1 Op de Coul ELM, Valkengoed lv, Sighem Av, et al. HIV en AIDS in Nederland. Bilthoven: RIVM, 2003.

2 Gras MJ, Weide JF, Langendam MW, et al. HIV prevalence, sexual risk behaviour and sexual mixing patterns among migrants in Amsterdam, The Netherlands. AIDS 1999;13:1953-62.

3 Fenton KA, Chinouya M, Davidson O, et al. HIV transmission risk among subSaharan Africans in London travelling to their countries of origin. AIDS 2001;15:1442-5.

4 Ministerie van Volksgezondheid/Pro Health. Nationaal strategisch plan voor een multi-sectorale aanpak van HIV/AIDS in Suriname 2004-2008. Paramaribo, Suriname: Ministerie van Volksgezondheid/Pro Health, 2003.

5 Camara B, Lee RK, Caffe S, et al. Status and trends; analysis of the Caribbean HIV/AIDS epidemic 1982-2002, Caribbean Epidemiology Centre (CAREC), 2004.

6 Op de Coul ELM, Coutinho RA, van der Schoot A, et al. The impact of immigration on env HIV-1 subtype distribution among heterosexuals in the Netherlands: influx of subtype B and non-B strains. AIDS 2001;15:2277-86.

7 Davies HTO, Crombie IK, Tavakoli M. When can odds ratios mislead? BMJ 1998;316:989-92.

8 De Graaf $\mathbf{R}$, van Zessen $\mathrm{G}$, Houweling $\mathrm{H}$, et al. Sexual risk of HIV infection among expatriates posted in AIDS endemic areas. AIDS 1997;11:1173-81.

9 Matteelli A, Carosi G. Sexually transmitted diseases in travelers. Clin Infect Dis 2001;32:1063-7.

10 Bellis MA, Hughes K, Thomson R, et al. Sexual behaviour of young people in international tourist resorts. Sex Transm Infect 2004;80:43-7.

11 Cabada MM, Echevarria JI, Seas CR, et al. Sexual behavior of international travelers visiting Peru. Sex Transm Dis 2002;29:510-13.

12 Hawkes S, Hart GJ, Johnson AM, et al. Risk behaviour and HIV prevalence in international travellers. AIDS 1994;8:247-52. 